\title{
EVALUATION OF INSECTICIDAL ACTIVITY OF HENNA LAWSONIA INERMIS LINN. EXTRACTS AGAINST THE COTTON LEAFWORM
}

\author{
MAHA I. ABD-EL RAZZIK ${ }^{1}$, OMAIMA A. BALBOUL ${ }^{1}$, SAHAR Y. ABD-ELAZIZ, ${ }^{3}$ \\ and SAHEIR F. EL-LLAKWAH ${ }^{2}$
}

1- Scale Insect and Mealy bug Research Department, Plant Protection Research Institute, Dokki, Giza, Egypt.

2- Department of pest physiology, Plant Protection Research Institute, Dokki, Giza, Egypt.

3- Department of Economic Entomology and Pesticides, Faculty of Agriculture Cairo University, Giza, Egypt

(Manuscript received 25 May 2018)

\begin{abstract}
$\mathrm{L}$

aboratory studies were carried out to evaluate the efficacy of Lawsonia inermis Linn. (Family: Lythraceae) against the Egyptian cotton leafworm, Spodoptera littoralis (Boisduval) (Lepidoptera: Noctuidae), Results of the five concentrations $(1000,2000,3000,4000$ and $5000 \mathrm{ppm})$ of water extract against $\left(1^{\mathrm{st}}\right.$ and $2^{\text {nd }}$ instars) and ( $3^{\text {rd }}$ and over instars $4^{\text {th }}, 5^{\text {th }}$ and $6^{\text {th }}$ ) of $S$. littoralis after 24 and 48 hrs showed that, the $S$. littoralis mortality significantly increased when water extract concentration increased. Also, results indicated that treatment with water extract affects the biochemical activities of the cotton leafworm $S$. littoralis. There are an alterations in all tested enzymes (Phenoloxidase, chitinase, protease, alkaline and acid phosphatases) and disturbances in protein levels under investigations when the cotton leafworm $S$. littoralis treated with Henna extract at all concentrations.
\end{abstract}

Keywords: Lawsonia inermis, Spodoptera littoralis, Toxicity and biochemical activities.

\section{INRODUCTION}

The Egyptian cotton leafworm Spodoptera littoralis (Boisd.) (Lepidoptera: Noctuidae) is one of the most destructive phytophagous insect pests in Egypt, not only to cotton but also to other field crops and vegetables (Kandil et al., 2003). This pest causes serious and considerable economic losses to many crops in both greenhouses and open fields. The noctuid $S$. littoralis is widely distributed all over the world; in Egypt, throughout Africa, Southern Europe, and several parts of Asia In addition to the cotton, the $S$. littoralis larvae infest more than 90 important plant species belonging to 40 families causing great losses in quantity and quality of the attacked crops (Kandil et al., 2003).

The prolonged application of chemical insecticides for controlling insect pests cause many problems such as pest resistance, environmental pollution, health hazards to farmers, food contamination and toxicity to non-target organism (parasitoids and predators). Most of these toxic chemicals enter into the food chain and cause pollution 
of the environment. So it is demanded to develop selective and environmentally safe methods that will result in better control of insect pest control. Recently, great attempts have been done at screening plants in order to develop new botanical insecticides as an alternative to the existing insecticides. There is renewed interest in the application of botanical pesticides for crop protection. Botanical pesticides are biodegradable and their use in crop protection is a practical sustainable alternative and reduces environmental contamination and human health hazards (Tripathi et al., 2009). As a continuation of this type of searching, we have selected Lawsonia inermis L. which is a well known medicinal plant in many parts of the world and commonly known as Henna. There is no many studies on the insecticidal activity of $L$. inermis leaves, so, the objective of this study is to investigate the insecticidal activity of water extract of $L$. inermis leaves against $\left(1^{\text {st }}\right.$ and $2^{\text {nd }}$ instars) and ( $3^{\text {rd }}$ and over instars $4^{\text {th }}$, $5^{\text {th }}$ and $6^{\text {th }}$ ) of cotton leafworm $S$. littoralis at different concentrations $(1000,2000,3000,4000$ and 5000ppm) and its effects on the following biochemical parameters: one defensive enzyme (Phenoloxidase), three hydrolytic enzymes (Chitinase, Acid and Alkaline phosphatase), one digestive enzyme (protease) and total proteins content at the same concentrations.

\section{MATERIALS AND METHODS}

\section{Plant collection and preparation}

Leaves of L. inermis were collected from El-Luxer, Governorate, Matthna Station, Plant Protection Researches Institute. The collected leaves of $L$. inermis were cleaned and dried. The dried plant materials were then pulverized into a coarse powder. The powdered leaves were successively extracted with water at room temperature. These extracts were evaporated under reduced pressure at $40^{\circ} \mathrm{C}$ using a rotary evaporator.

\section{Bioassay of henna extract against $S$. littoralis Dipping technique}

Five concentrations of henna $L$. inermis extract were prepared in water ranged from 1000 to $5000 \mathrm{ppm}$ as required for the bioassay tests against ( $1^{\text {st }}$ and $2^{\text {nd }}$ larval instars) and ( $3^{\text {rd }}$ and over larval instars) of cotton leafworm S. littoralis. The castor bean leaves were dipped in each concentration of the plant extracts for 20 second and left to dry then five replicates of 10 larvae of each concentration were fed on the treated leaves for 24 and 48 hrs. The surviving larvae were transferred to clean cups and supplied daily with untreated leaves until pupation. For control, plant leaves were dipped in fresh water. Mortality was recorded daily (24 and $48 \mathrm{hrs)}$ ) after treatment and the $\mathrm{LC}_{50}$ s were determined. 


\section{Spraying technique):}

The leaf spraying technique was used as toxicity test for henna $L$. inermis extracts against ( $1^{\text {st }}$ and $2^{\text {nd }}$ instars) and ( $3^{\text {rd }}$ and over instars) of cotton leafworm insect $S$. littoralis. Uninfested plant leaves were selected from castor and placed in a petri dishes ( $9 \mathrm{~cm}$ diameter, $1 \mathrm{~cm}$ high by $3.5 \mathrm{~cm}$ diameter). Infested castor leaves were transported to the laboratory and $S$. littoralis individuals were separated from it and put in a container. After that each dish, leaf and $S$. littoralis individuals were sprayed with the different concentrations $(1000,2000,3000,4000$ and 5000ppm) of water henna extract. Dishes were leaved to dry at ambient temperature and covered. Five replicates were conducted for each treatment. A control leaf was spraying by water. After application, Petri dishes placed in laboratory conditions and examined for mortality and life after 24, 48 and 72 hrs.

\section{Biochemical assays:}

\section{Determination of enzymatic activities.}

\section{Defensive enzyme assay (Phenoloxidase):}

Phenoloxidase activity of $S$. littoralis $4^{\text {th }}$ instar larvae was determined according to modifications of Ishaaya (I971), in a reaction mixture consisting of $0.5 \mathrm{ml}$ phosphate buffer (0.1 M, PH 7), $200 \mathrm{ml}$ enzyme solution and $200 \mathrm{ml}$ catechol solution (2\%). Prior to the initiation of the reaction, the substrate and other ingredients of the reaction mixture were separately incubated at the optimum temperature of the reaction $\left(25^{\circ} \mathrm{C}\right)$. The enzyme reaction was initiated by adding catechol solution, then after exactly $1 \mathrm{~min}$, the optical density was determined. Zero adjustment was against sample blank. The phenoloxidase activity was determined as O.D. units $10^{3}$ at an absorbency of $405 \mathrm{~nm}$.

\section{Digestive enzyme assay (Protease):}

The proteolytic activity of $S$. littoralis $4^{\text {th }}$ instar larvae was determined according to Birk, et al., (1962). The proteolytic activity was determined from bovine serum albumin standard curve; as O.D.units $\times 10^{3} /$ larvae body weight and the absorbance at $280 \mathrm{~nm}$.

\section{Hydrolytic enzymes activities.}

Acid phosphatase (AC-P) and alkaline phosphatase (ALK-P) activities were determined according to the methods described by Powell and Smith (1954), in 100 $\mathrm{mg}$ tissue of whole homogenated $4^{\text {th }}$ instar larvae.

Chitinase was assayed using a 3,5-dinitrosalicylic acid reagent to determine the free aldehyde groups of hexoaminase liberated on chitin digestion according to the method described by Ishaaya and Casida (1974). 


\section{Determination of energy reserve (Total proteins).}

Protein content of $S$. littoralis $4^{\text {th }}$ instar larvae samples was estimated spectrophotometrically by the method of Bradford (1976). Total proteins contents were calculated and expressed as $\mathrm{mg} / \mathrm{g}$ of larvae body weight.

\section{Statistics:}

The results were analyzed by one way analysis of variance (ANOVA) using costat statistical software (cohort software,Berkeley). When the ANOVA statistics were significant $(P<0.05)$, means were compared by the Duncan's multiple range test.

\section{RESULTS AND DISCUSSION}

\section{Dipping technique}

The results of toxicity assays by dipping technique of Henna $L$. inermis extract against ( $1^{\text {st }}$ and $2^{\text {nd }}$ instars) and ( $3^{\text {rd }}$ and over instars) of cotton leafworm insect $S$. littoralis as represented in the table (1), showed that, water extract of henna achieved significant high mortality percentages against ( $1^{\text {st }}$ and $2^{\text {nd }}$ instars) and ( $3^{\text {rd }}$ and over instars). The highest concentration $5000 \mathrm{ppm}$ was recorded $100 \%$ mortality against $\left(1^{\text {st }}\right.$ and $2^{\text {nd }}$ instars) and ( $3^{\text {rd }}$ and over instars) after 24 and 48 hrs. The higher toxicity rate of water extract against ( $1^{\text {stand }} 2^{\text {nd }}$ instars) were 65.00 and $97.50 \%$ at the concentration 4000ppm, after 24 and 48 hrs., respectively and were 60.00 and 77.50 $\%$, with the concentration $3000 \mathrm{ppm}$ after the same two times respectively. On other hand, the toxicity rate against ( $3^{\text {rd }}$ and over instars) after $24 \mathrm{hr}$. were 25.00 and 40.00 $\%$, and after $48 \mathrm{hr}$. were 55.00 and $60.00 \%$, at the two concentrations (3000 and 4000ppm), respectively. Concentration 2000 ppm caused (45.00 and $15.00 \%$ ) and (45.00 and $15.00 \%)$ mortalities against ( $1^{\text {st }}$ and $2^{\text {nd }}$ instars) and ( $3^{\text {rd }}$ and over instars) after 24 and 48 hrs., respectively. The lowest mortality (32.50 and 37.5\%) caused by concentration 1000 ppm against ( $1^{\text {stand }} 2^{\text {nd }}$ instars) after 24 hrs and (5.00 and10.00\%)

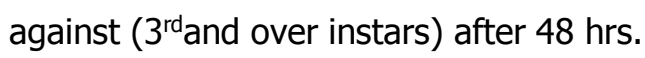

The least lethal concentration ( $\mathrm{LC}_{50}$ ) values obtained from probit analysis for mortality values after 24 and 48 hours of each L. inermis extract applied are given in the Table (1). According to the results, the Henna water extract has the lowest LC $_{50}$ value 1933.67 and $1497.56 \mathrm{ppm}$ after 24 and 48 hours against ( $1^{\text {st }}$ and $2^{\text {nd }}$ instars), respectively. While, $\mathrm{LC}_{50}$ values of Henna water extract against ( $3^{\text {rd }}$ and over instars) were 3498.56 and 2390.08 ppm after 24 and 48 hours respectively. In general LC 50 values of Henna water extract after $48 \mathrm{hr}$ were lower than $24 \mathrm{hr}$ against $\left(1^{\text {st }}\right.$ and $2^{\text {nd }}$ instars) and ( $3^{\text {rd }}$ and over instars). Among all, Henna water extract after $48 \mathrm{hr}$. of exposure was found to be more effective against $S$. littoralis than after $24 \mathrm{hr}$. Overall results indicated that, water extract of Henna $L$. inermis exhibited toxicity rate with 
concentration dependent and the efficiency of those extracts against cotton leafworm S. littoralis increased when their concentrations and time exposure increased.

The insecticidal effect of $L$. inermis leaves against insects was reported in many researches and confirmed with our findings. The study of Kamal et al. (2016) indicated that, methanolic extract of leaf of $L$ inermis was highly effective against red flour beetle, Tribolium castaneum and the mortality percentage was directly proportional to the level of concentration of plant extract. Also, The toxic effect of plant extracts against $S$. littoralis was confirmed by Mesbah et al. (2006) who reported that, most of the evaluated plant oils were found to have an insecticidal effect on the ${ }^{\text {th }}$ instar larvae of the cotton leaf-worm, S. littoralis. The development of the treated $4^{\text {thl }}$ larval instar was blocked due to treatment with the tested plant oils. In addition, results of Abdel-Aziz et al. (2013) showed that all the tested oils (thyme, bitter and neem) caused deformations with various degrees for larvae, pupae and adults resulted from the treated $2^{\text {nd }}$ and $4^{\text {th }}$ instar larvae of $S$. littoralis .

The feeding on henna extract in the diet resulted in irreversible damage to physiological processes essential to the development of $S$. littoralis. Several anomalies, possibly related to defective moulting, were observed with the most concentrations, but particularly at $4000 \mathrm{ppm}$ and $5000 \mathrm{ppm}$. Most of the tested extract concentrations significantly inhibited larval growth compared to the control. From our results we noticed that the development of the treated larval instars were blocked, the cuticle colour turned to a uniform dark grey, dorsally swollen and the larva to pupa moult stopped due to larvae instars fed on castor leaves treated with $L$. inermis extract. The results showed no clear evidence of any direct antifeedant effect at the concentrations tested which indicates that the $L$. inermis extract acted principally as a larval growth inhibitor and also an inhibitor of chitin synthesis (anti moulting agent) rather than antifeedants causing disruption of the insect development, abnormal larvae that were lead finally to death. However, additional detailed experiments are needed to determine the mechanism of the effects of our extract on insects, and shed light on these mechanisms.

Our results are in agreement with Martinez and Emden (2001) who showed that, a two-day feeding period promoted prolongation of the larval instars, reduction in the Mean Relative Growth Rate (MRGR), moulting disruption, morphological anomalies and mortality of $S$. littoralis in a dose-dependent manner. In an analogous study, the tested essential and/or volatile oils acted principally as Insect Growth Inhibitors (IGIs) rather than antifeedants causing disruption of the larvae of the cotton leaf-worm $S$. littoralis development, abnormal larvae, pupae and adults that were lead finally to death (Mesbah et al 2006). 
The results obtained here are promising for the control of $S$. littoralis. A two-day feeding period was enough to promote prolongation of the larval instars, moulting disruption, morphological anomalies and mortality of the species. In conclusion, the present results indicate that Henna extract possessed toxic effects on S. littoralis and inhibited growth through various metabolic processes. Furthermore, the results suggest an interesting opportunity to develop bio-insecticides based on extracts from Henna extract for use in integrated pest management of insect pests that may affect crop production.

\section{Spraying technique}

Results in Table (2) indicated that after 24 hrs. of spraying water extract of $L$. inermis leaves, all different concentrations (1000 to 5000ppm) not caused any significant mortality percentages against cotton leafworm $S$. littoralis. The highest percent mortality (30.77\%) was observed in water extract at concentration 5000 ppm compared to other treatments after $72 \mathrm{hr}$. However, in general there is no significant increase in toxicity of water extract was observed with increasing of concentrations and time against $S$. littoralis and the percent mortality ranged between $2.77 \%$ to $13.62 \%$ after $24 \mathrm{hr}$. from $6.67 \%$ to $23.33 \%$ after $48 \mathrm{hr}$. and from $10.75 \%$ to $30.77 \%$ after $72 \mathrm{hr}$.

Dipping technique caused higher toxicity rate against cotton leafworm insect S. littoralis than spray technique at all concentrations of the study. Generally, our results showed that the dipping technique was more efficient than the spraying technique in control of cotton leafworm insect $S$. littoralis.

\section{Biochemical analysis}

In the present study, effect of water extract of $L$. inermis on biochemistry of the cotton leaf-worm, $S$. littoralis was evaluated and the estimations were done for analyzing the activity of one defensive enzyme (Phenoloxidase), three hydrolytic enzymes (Chitinase, Acid and Alkaline phosphatase), one digestive enzyme (protease) and total proteins content at the five different concentrations.

\section{Effects of water $\boldsymbol{L}$. inermis extract on enzymatic activities of $\boldsymbol{S}$. littoralis. *Effect on phenoloxidase and chitinase enzyme activities.}

Results in Table (3) showed that, there is significantly increasing in the phenoloxidase enzyme activity (10.30, 9.90, 13.77, 14.30 and 20.23 O.D. units/min/gm) compared to control $(9.08 \mu g$ D,L alanine/min $/ g . b . w t)$ with the increasing of the five assessed concentrations, respectively. Also, there is increasing in the chitinase enzyme activity (1076.60, 814.30, 1396.60, 1523.33 and 2011.33 $\mu g \mathrm{NAGA} / \mathrm{min} /$ g.b.wt) compared to control (969.33 $\mu$ g NAGA/min/g.b.wt) with the same concentrations, respectively except concentration $2000 \mathrm{ppm}$. Our results are in 
agreement with these finding by Abd El-Mageed and Shalaby (2011) who noticed that, the most effective insecticide Kingbo, caused a significant increase in phenoloxidase activity of S. littoralis (2858.33\% higher than in the control) followed by engeo (1191.67\%) and chlorosan (291.67\%). Phenoloxidase activity elevation because it's an oxidative enzyme in insects and playing an important role in the development and immunity of insects (Ashida and Brey 1995).

The changes in the chitinase activity in S. littoralis larvae was observed by many authors. Abdel-Aziz et al. (2013) demonstrated that, the tested oils (thyme, bitter and neem) caused highly significant stimulation in chitinase activity against $4^{\text {th }}$ and $6^{\text {th }}$ instars of $S$. littoralis for 48 hrs and the most effective ones was thyme followed by bitter and neem compared with control. Also, Abd El-Mageed and Shalaby (2011) found that chitinase activity was increased more than control after treatment of cotton leafworm larvae $S$. littoralis by mixtures of bioinsecticids. Chitinase activity increasing interpreted by $\mathrm{Yu}$ and Terriere, (1977) who stated that, the increase in chitinase activity could be attributed to the secondary effect of chitin synthesis inhibitor, or may be a secondary effect for the reduced activity of $\beta$-ecdysone metabolizing enzymes, followed by $\beta$-ecdysone accumulation which result in hyperchitinase activity.

\section{Effect on hydrolytic enzyme activity (Acid and Alkaline phosphatase)}

Results in Table (4) showed that, alkaline phosphatase caused continuous gradual decrease in enzyme activity with increasing concentrations compared to control except at concentration 2000ppm. Also, acid phosphatase activity of $S$. littoralis significantly decreased at five different tested concentrations compared to control. In general acid and alkaline phosphatase enzyme activities were decreased with the increasing of the assessed concentrations. From these findings, acid and alkaline phosphatases activities are depending on the plant extract concentrations.

The inhibition of acid and alkaline phosphatases activities with increasing plant extract concentrations seem to be in agreement with the results reported by Mead et al. (2016) who stated that, both mahlab and KZ mineral oil decreased the activities of alkaline and acid phosphatases of $S$. littoralis as compared to the control, with the exception of mahlab oil on acid phosphatase. Also, our results were confirmed by Younes et al., (2011) who reported that, the acid and alkaline phosphatases activities in treated larvae of khapra beetle Trogoderma granarium were less than in control one when using garlic, onion, sunflower, and rosemary oils in the treatments. Also, they stated that, the inhibition of acid phosphatase activity that could be due to the presence of anti-insect protein in the tested oils that its defense function is correlated 
with acid phosphatase activity and cause loss of acid phosphatase activity and significantly delayed their development of insects and increases their mortality.

\section{Effects on energy reserve proteins and its enzyme (protease). Effect on total proteins:}

Protein content of the treated larvae of $S$. littoralis show significant increase with increasing of the five tested concentrations as compared with the control (Table 5). Protein content significantly increased in all treatments, generally, changes in protein content probably reflect the balance between synthesis, storage, transport and degradation of structural and functional nutrients during ontogeny as well as response to particular physiological conditions. The increase in protein content with different treatments may be attributed to the increased activity of protein biosynthesis. Many workers obtained similar findings on other species of insects. Shakoori and Saleem (1991) attributing the greater protein synthesis with insecticidal treatment to synthesis of the proteinases needed for insecticide detoxification. This finding may be due to the conversion of carbohydrates and lipids to proteins as stated by Kinnear et al. (1968) who suggested that increased protein levels was due to increased synthesis of new proteins by the fat body, haemolymph and other tissues of the larvae.

\section{Effect on digestive activity (Protease)}

The results obtained in Table (5) indicated that protease activity increased significantly with increasing of concentrations as compared to control. These results are in agreement with those reported by Abdel-Aal et al., (2012) recorded significant increase in protease of $S$. littoralis larvae with treated with Diple $2 x$ alone and its mixture with two insecticides. In the same context, Abdel-Aziz et al. (2013) revealed that, the protease activity fluctuated between increase and decrease. Bitter and thyme treatments exhibited remarkable inhibition in protease activity. While high significant stimulation was recorded neem treatment compare with control.

The secondary metabolites of plants are compounds with wide range of insecticidal activity. Phytochemical investigations on leaf and fruit of $L$. inermis showed the presence of many secondary metabolites such as tannins, cardiac glycosides, saponins, flavonoid, steroids, phenolic derivatives, coumarins, xanthones, naphthoquinone derivatives, alkaloid and terpenoids and these compounds of $L$. inermis had great impact on insecticidal activities Kamal et al. (2016). The results of Adedeji et al. (2017) showed that the extractives compounds from L. inermis leaves such as alkaloids, phenols, tannins and saponins had significant biocide actions against wood termites. On the other hand Karamanoli et al. (2011) reported that tannin combine with protein inhibit the enzyme activity and reduce the availability of protein in haemolymph insect. Naphthoquinones and Coumarins are wide-spread 
phenolic compounds in nature, Juglone, lawsone, plumbagin (Naphthoquinone) and Esculetin, fraxetin (Coumarin ) extracted from $L$. inermis leaves have significant antibacterial, antifungal, antiviral, insecticidal, anti-inflammatory, and antipyretic properties (Abulyazid, et al. 2013). The exact mechanism action of $L$. inermis is not yet known, the insecticidal activity of $L$. inermis may be attributed to not only a single active compound but to a variety of bioactive compounds. So, the pesticidal activity of $L$. inermis against $S$. littoralis may be due to the presence of these different bioactive compounds especially naphthoquinone derivatives. The overall results of this study reported the toxic effect of leaf of $L$. inermis on $S$. littoralis and our next approach will be targeted to isolate possible active compounds.

\section{CONCLUSION}

It was perceived from the present study, Henna leaves extracts showed alterations in all the enzymes and protein levels under investigations when larvae of $S$. littoralis treated with Henna extract at all concentrations. In conclusion these findings of the present study suggest that water extract can be used to control $S$. littoralis but further study needs to be conducted to know the compatibility of these extracts in insect control to help in integrated pest management strategy.

Table 1. Effect of five different concentrations of water Henna extract on larvae mortality of Spodoptera littoralis by dipping technique at 24 hours and $48 \mathrm{hr}$.

\begin{tabular}{|c|c|c|c|c|}
\hline \multirow{3}{*}{ Conc./ppm } & \multicolumn{4}{|c|}{ Mortality \pm SD (\%) } \\
\hline & \multicolumn{2}{|c|}{$1^{\text {st }}$ and $2^{\text {nd }}$ Instars } & \multicolumn{2}{|c|}{$3^{\text {rd }}$ and over Instars } \\
\hline & 24hr. & 48hr. & 24hr. & 48hr. \\
\hline Control & 0.00 & 0.00 & 0.00 & 0.00 \\
\hline 1000 & $32.50 \pm 17.08^{c}$ & $37.50 \pm 5.00^{c}$ & $5.00 \pm 5.00^{c}$ & $10.00 \pm 5.77^{c}$ \\
\hline 2000 & $45.00 \pm 28.87^{b c}$ & $55.00 \pm 25.09^{b c}$ & $15.00 \pm 9.57^{\mathrm{bc}}$ & $50.00 \pm 10.00^{b}$ \\
\hline 3000 & $60.00 \pm 11.55^{\mathrm{bc}}$ & $77.50 \pm 5.70^{\mathrm{ab}}$ & $25.00 \pm 15.00^{\mathrm{bc}}$ & $55.00 \pm 9.57^{b}$ \\
\hline 4000 & $65.00 \pm 5.00^{b}$ & $97.5 \pm 5.00^{\mathrm{abc}}$ & $40.00 \pm 8.16^{b}$ & $60.00 \pm 8.16^{b}$ \\
\hline 5000 & $100.00 \pm 0.00$ & $100.00 \pm 0.00^{\mathrm{a}}$ & $100.00 \pm 0.00^{\mathrm{a}}$ & $100.00 \pm 0.00^{\mathrm{a}}$ \\
\hline$L_{50}$ & 1933.67 & 1497.56 & 3498.56 & 2390.08 \\
\hline $\mathbf{F}$ & $10.39 * * *$ & $5.877^{* *}$ & $17.235^{* * *}$ & $14.83 * * *$ \\
\hline LSD & 24.15 & 22.533 & 27.24 & 25.15 \\
\hline
\end{tabular}


Table 2. Toxicity effect of five different concentrations of water Henna extract on larvae mortality of Spodoptera littoralis by spraying technique at 24, 48and $72 \mathrm{hrs}$.

\begin{tabular}{|c|c|c|c|}
\hline \multirow{2}{*}{ Conc./ppm } & \multicolumn{3}{|c|}{ Mortality \pm SD (\%) } \\
\hline & 24hr. & 48hr. & $72 \mathrm{hr}$. \\
\hline Water control & 0.00 & 0.00 & 0.00 \\
\hline 1000 & $2.77 \pm 4.80^{\mathrm{a}}$ & $6.67 \pm 1.56^{\mathrm{b}}$ & $10.75 \pm 5.00^{\mathrm{a}}$ \\
\hline 2000 & $6.67 \pm 1.52^{\mathrm{a}}$ & $9.05 \pm 7.94^{\mathrm{ab}}$ & $21.50 \pm 9.49^{\mathrm{a}}$ \\
\hline 3000 & $11.43 \pm 3.50^{\mathrm{a}}$ & $10.67 \pm 2.89^{\mathrm{ab}}$ & $26.67 \pm 10.00^{\mathrm{a}}$ \\
\hline 4000 & $10.67 \pm 8.66^{\mathrm{a}}$ & $16.11 \pm 6.63^{\mathrm{ab}}$ & $28.50 \pm 15.10^{\mathrm{a}}$ \\
\hline 5000 & $13.62 \pm 5.00^{\mathrm{a}}$ & $23.33 \pm 5.77^{a}$ & $30.77 \pm 9.44^{a}$ \\
\hline $\mathbf{L C}_{50}$ & 62382.75 & 46665.04 & 14014.75 \\
\hline $\mathbf{F}$ & $0.637^{\text {ns }}$ & $2.33^{\text {ns }}$ & $0.729^{\text {ns }}$ \\
\hline LSD & 16.09 & 14.75 & 30.44 \\
\hline
\end{tabular}

Table 3. Effects of five different concentrations of Henna extract on defensive enzyme phenoloxidase and chitinase activities of treated $4^{\text {th }}$ instar $S$. littoralis larvae.

\begin{tabular}{ccc}
\hline & \multicolumn{2}{c}{ Enzyme activity \pm SD } \\
\cline { 2 - 3 } Conc./ ppm & $\begin{array}{c}\text { Phenoloxidase } \\
(\boldsymbol{O} . \boldsymbol{D} . \text { units } / \mathbf{m i n} / \mathbf{g m})\end{array}$ & $\begin{array}{c}\text { Chitinase } \\
(\boldsymbol{\mu g} \mathbf{~ N A G A} / \mathbf{m i n} / \mathbf{g} . \mathbf{b} . \mathbf{w t})\end{array}$ \\
\hline Control & $9.08 \pm 0.530^{\mathrm{d}}$ & $969.33 \pm 17.04^{\mathrm{e}}$ \\
\hline 1000 & $10.30 \pm 0.264^{\mathrm{c}}$ & $1076.67 \pm 20.82^{\mathrm{d}}$ \\
\hline 2000 & $9.90 \pm 0.435^{\mathrm{c}}$ & $814.33 \pm 22.28^{\mathrm{f}}$ \\
\hline 3000 & $13.77 \pm 0.321^{\mathrm{b}}$ & $1396.67 \pm 25.17^{\mathrm{c}}$ \\
\hline 4000 & $14.30 \pm 0.100^{\mathrm{b}}$ & $1523.33 \pm 31.21^{\mathrm{b}}$ \\
\hline 5000 & $20.23 \pm 0.680^{\mathrm{a}}$ & $2011.33 \pm 72.28^{\mathrm{a}}$ \\
\hline F value & $\mathbf{2 7 9 . 6 5 * * *}$ & $\mathbf{4 4 2 . 5 2 * * *}$ \\
\hline LSD & $\mathbf{0 . 7 6 7}$ & $\mathbf{6 5 . 1 5}$ \\
\hline
\end{tabular}

Table 4. Effect of five different concentrations of Henna extract on two hydrolytic enzymes activities of treated $4^{\text {th }}$ instar Spodoptera littoralis larvae.

\begin{tabular}{|c|c|c|}
\hline \multirow[b]{2}{*}{ Conc./ppm } & \multicolumn{2}{|c|}{ Enzyme activity \pm SD } \\
\hline & $\begin{array}{r}\text { Acid phosphatase } \\
\text { ( } \mu g \text { anaphthol/min/gm) }\end{array}$ & $\begin{array}{c}\text { Alkaline phosphatase } \\
\left(U \times 10^{3} / g . b . w t .\right) \\
\end{array}$ \\
\hline Control & $235.33 \pm 7.57^{\mathrm{a}}$ & $1088.67 \pm 34.42^{\mathrm{a}}$ \\
\hline 1000 & $204.67 \pm 9.07^{\mathrm{b}}$ & $978.33 \pm 100.75^{\mathrm{b}}$ \\
\hline 2000 & $228.67 \pm 13.31^{\mathrm{a}}$ & $792.00 \pm 23.06^{c}$ \\
\hline 3000 & $205.00 \pm 5.291^{\mathrm{b}}$ & $743.00 \pm 15.72^{c}$ \\
\hline 4000 & $194.67 \pm 5.507^{\mathrm{b}}$ & $725.00 \pm 18.73^{c}$ \\
\hline 5000 & $125.67 \pm 5.5071^{\mathrm{c}}$ & $635.00 \pm 5.51^{d}$ \\
\hline F-Value & $73.68 * * *$ & 42.25* \\
\hline LSD & 14.03 & 81.19 \\
\hline
\end{tabular}


Table 5. Effect five different concentrations of Henna extract on total proteins content and digestive enzyme (protease) of $4^{\text {th }}$ instar Spodoptera littoralis larvae.

\begin{tabular}{|c|c|c|}
\hline & Energy reserves \pm SD & Enzyme activity \pm SD \\
\hline Conc./ppm & $\begin{array}{l}\text { Total Proteins } \\
\text { (mg/g.b.wt.) }\end{array}$ & $\begin{array}{c}\text { Proteases } \\
(\mu g D, L \text { alanine } / \mathrm{min} / \mathrm{g} . \boldsymbol{b}, w t)\end{array}$ \\
\hline Control & $10.93 \pm 0.71^{c}$ & $1.99 \pm 0.085^{\mathrm{d}}$ \\
\hline 1000 & $12.70 \pm 0.70^{b}$ & $2.15 \pm 0.145^{\mathrm{cd}}$ \\
\hline 2000 & $11.60 \pm 0.76^{c}$ & $3.00 \pm 0.152^{\mathrm{a}}$ \\
\hline 3000 & $11.33 \pm 0.98^{c}$ & $2.51 \pm 0.090^{\mathrm{b}}$ \\
\hline 4000 & $12.47 \pm 2.98^{b}$ & $2.22 \pm 0.105^{c}$ \\
\hline 5000 & $14.20 \pm 2.85^{\mathrm{a}}$ & $2.43 \pm 0.087^{b}$ \\
\hline F-Value & $18.63 * * *$ & $28.64 * * *$ \\
\hline LSD & 0.85 & 0.203 \\
\hline
\end{tabular}

\section{REFERENCES}

1. Abd El-Aal, E. A. and T. A. El- Sheikh 2012. Efficiency of Diple 2x (Bacillus thuringiensis var. kurstakl) alone and its mixture with two insecticides against the Egyptian cotton leafworm Spodoptera littoralis (Lepidoptera: Noctuidae). Egyp. Acad. J. Biolog. Sci., 4 (1): 61-68.

2. Abd El-Aziz H. S., H. H. Osman., S. Z. Sayed and E. E. El-Gohary 2013. Effect of certain plant oils on some biological and biochemical aspects on the cotton leafworm Spodoptera littoralis. Egypt. Acad. J. biolog. Sci., 6 (3): 69-80.

3. Abd El-Mageed A. E. M. and S. E. M. Shalaby 2011.Toxicity and biochemical impacts of some new insecticide mixtures on cotton leafworm Spodoptera littoralis (Boisd.). Plant Protect Sci., 47(4):166-175.

4. Abulyazid I., M.E. Elsayed and M. A. Ragaa 2013. Biochemical study for the effect of henna (Lawsonia inermis) on Escherichia coli Arabian Journal of Chemistry 6: 265-273.

5. Adedeji G. A., O. Ogunsanwob and T. Elufioyec 2017. Quantifications of phytochemicals and biocide actions of Lawsonia inermis linn. Extracts against wood termites and fungi. International Biodeterioration and Biodegradation, 116:155-162.

6. Ashida, M. and Brey, P. 1995. Role of the integument in insect defense: prophenoloxidase cascade in the cuticular matrix. Proceedings of the National Academy of Sciences USA, 92: 10698-10702.

7. Birk, Y.; I. Harpaz; I. Ihasaya and A. Bondi. 1962. Studies on the proteolytic activity of the beetles Tenebrio and Tribolium. J. Insect Physiol., 8:417-429.

8. Bradford, M. M. 1976. A rapid and sensitive method for the quantitation of microgram quantities of proteins utilizing the principle of protein-dye binding. Anal. Biochem., 72:248-254.

9. Ishaaya, I. and Casida J.E. 1974. Dietary TH 6040 alters composition and enzyme activity of housefly larval cuticle. Pestic Biochem Physiol 4: 484-490. 
10. Ishaaya, I. I971. Observations on the phenoloxidase system in the armored scales Aonidiella aurantii and chrysomphalus aonidum. Comp. Biochem. physiol. ,V(39) B:935-943.

11. Kamal K. B., Nusrat S. and M.A. Rabbi. 2016. Evaluation of insecticidal activity of Lawsonia inermis Linn. against the red flour beetle, Tribolium castaneum (Herbst) NPAIJ, 12(1), 8-11.

12. Kandil, M.A., N.F. Abdel-Aziz and E.A.Sammour. 2003. Comparative toxicity of chlorfluazuron and leufenuron against cotton leafworm, Spodoptera littoralis (Boisd.). Egypt. J. Agric. Res. NRC., 2: 645-661.

13. Karamanoli K., P. Bouligaraki., H.I.A. Constantinidou and S.E. Lindow 2011. Polyphenolic compounds on leaves limit iron availability and affect growth of epiphytic bacteria. Annals of Applied Biology, 159: 99-108.

14. Kinnear, J.F. 1968. Protein and lipid in haemolymph of late larva of Calliphora. Aust. J. Biol. Sci., 2x: 1033-1045.

15. Martinez S. S. and H. F. Emden. 2001. Growth disruption, abnormalities and mortality of Spodoptera littoralis (Boisduval) (Lepidoptera: Noctuidae) caused by azadirachtin. Neotropical Entomology 30(1): 113-125.

16. Mead, H. M., S. N. El-Shafiey, H. M. Sabry. 2016. Chemical constituents and ovicidal effects of mahlab, Prunus mahaleb L. kernels oil on cotton leafworm, Spodoptera littoralis (Boisd.) eggs. Journal Of Plant Protection Research, 56, (3):279-290.

17. Mesbah, H. A; Mourad, A. K; Rokaia, A. Z. M. 2006. Efficacy of some plant oils alone and/or combined with different insecticides on the cotton leaf-worm Spodoptera littoralis (Boisd.) (Lepidoptera:Noctuidae) in Egypt. Commun Agric Appl Biol Sci. 71(2 Pt B):305-28.

18. Powell, M.E.A., Smith M.J.H. 1954. The determination of serum acid and alkaline phosphatase activity with 4-aminoantipyrine (A.A.P.). Journal of Clinical Pathology 7 (3): 245-248.

19. Shakoori A.R. and M.A. Saleem. 1991. Comparative biochemical composition of susceptible (FSSII) and two malathion resistant (CTC12 and Pakistan) strains of Tribolium castaneum (Coleoptera: Tenebrionidae) Pakistan, J.Zool., 23:1-16.

20. Tripathi, A.K., Upadhyay, S. Bhuiyan, M. and P.R. Bhattacharya. 2009. A review on prospects of essential oils as biopesticides in insect-pest management. Journal of Pharmacognosy and Phytotherapy. , 1(5):052-063.

21. Younes, F. Salah, I. Othman, A. Elkersh, N. S. Youssef, G. and Omar A. 2011.. Effect of seven plant oils on Bichemical parameters in khapra beetle Trogoderma granarium Everts (Coleoptera: Dermestidae) Egypt. J. Exp. Biol. (Zool.), 7(1): 5361.

22. Yu, S.J. and L.C. Terriere. 1977. Ecdysin metabolism by soluble enzymes from three species of Diptera and its inhibition by the insect growth regulatar TH6040, Pestic. Biochem. Physiol. 7: 48-55. 


\section{تقييم النشاط الابادى لمستخلص الحنة ضد دودة ورق القطن}

$$
\begin{aligned}
& \text { مها ابراهيم عبدالرازق } 1 \text { ، أومايمة عبد الفتاح بلبول } 1 \text { ، } \\
& \text { سحر ياسين عبد العزيز3 } \\
& \text { 1- قسم بحوث الحشرات القشرية والبق الدقيقى- معهد بحوث وقاية النباتات } \\
& \text { 2- قسم فسيولوجيا الأفات - معهد بحوث وقاتية النباتات } \\
& \text { 3- قسم الحشرات الأقتصادية والمبيدات - كلية الزراعة - جامعة القاهرة }
\end{aligned}
$$

تمت الدراسات المعملية لتقييم كفاءة مستخلص نبات الحنة ضد دودة ورق القطن و إثنارت نتائج التركيزات الخمسة (ppm 5000و4000,3000,2000,1000) من المستخلص المائى ضد العمر

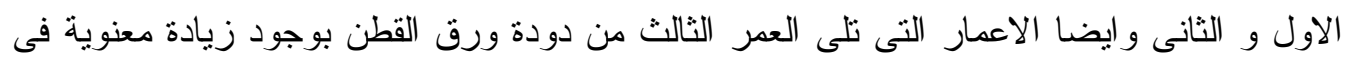

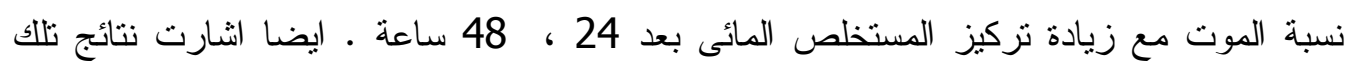

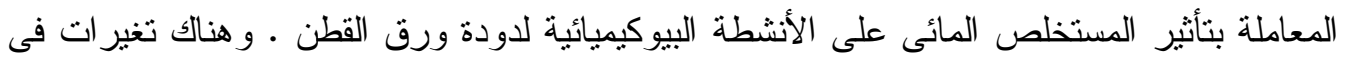

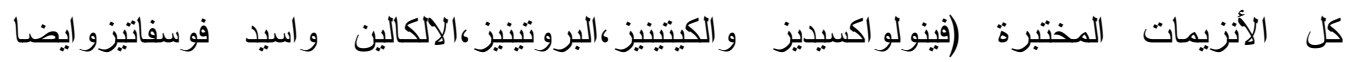
اضطر اب فى مستويات البروتين تحت الاختبارات عند معاملة دودة ورق القطن بكل تركيزات 
